http://dx.doi.org/10.12775/szhf.2014.010

\title{
Pogranicza psychologii sukcesu, czyli zdrowe podejście do rozporządzania czasem
}

\section{Wstęp}

Marian Kinget w swej książce One Being Human zaznacza, że jednostki ludzkie są zakotwiczone $\mathrm{w}$ wielopłaszczyznowym obszarze, a przede wszystkim w nieprzerwanie przepływającym strumieniu, który nazywa czasem. W nieustannie uciekającej nam przez palce „chwili obecnej” powinniśmy cieszyć się wyobrażoną przyszłością i przeszłością ${ }^{1}$. Jak podkreśla Kinga Tucholska w swej publikacji Kompetencje temporalne jako wyznacznik dobrego funkcjonowania, Kinget odnosi się w swej teorii do Alfreda Korzybskiego, który to w dziele Timie - Winding. The general theory podkreśla, że człowieka cechuje interesująca zdolność „wiązania” czasu, dzięki czemu potrafi on transcendować momenty teraźniejsze poprzez rzutowanie myślami w przeszłość i snucie planów dotyczących przyszłości ${ }^{2}$. Ludzie, przynajmniej w większości, mają świadomość perspektywy czasu, wiedzą, że są istotami skończonymi, żyjącymi w sprecyzowanej czasoprzestrzeni, dlatego też nie są tylko

${ }^{1}$ M. Kinget, On being human. A systematic view, New York 1975, s. 33.

${ }^{2} \mathrm{~K}$. Tucholska, Kompetencje temporalne jako wyznacznik dobrego funkcjonowania, Lublin 2007, s. 38. 
i wyłącznie kompletem nagromadzonych doświadczeń ${ }^{3}$. Nieustannie się rozwijają, przetwarzają dane pochodzące zarówno ze świata wewnętrznego, jak i z zewnętrznego. Wobec informacji trafiających do obszarów świadomości dana jednostka stara się zachować dystans. Przeszłość każdego z nas jest reinterpretowana i w toku egzystencjalnego progresu nabiera nowych znaczeń. Potwierdzają to słowa Kingi Tucholskiej: „Restrukturyzowanie przeszłych doświadczeń umożliwia człowiekowi 'odmienienie’ przeszłości”"

\section{Zimbardowska perspektywa czasowości}

Niekiedy spotykam ludzi, którzy nieustannie cierpią na chroniczny „brak czasu”, co może skutkować długotrwałym poczuciem melancholii oraz destrukcyjnym, niszczącym wewnętrzną i zewnętrzną tkankę człowieka stresem i poczuciem niechcenia.

Philip Zimbardo w swej pobudzającej myślenie książce Paradoks czasu stara się nam ukazać i wyłuszczyć problem XXI wieku, jakim jest stale rosnące poczucie „braku czasu”, będące następstwem nieumiejętnego nim zarządzania. Amerykański psycholog społeczny podkreśla, że ludzie nie szanują podarowanego im czasu oraz postępują tak, jakby byli istotami nieśmiertelnymi. Co ważne, marnotrawią go na bezproduktywne wpatrywanie się w ekran telewizora. Z przeprowadzonych przez stanfordzkiego profesora badań wynika, że ponad $40 \%$ amerykańskiego społeczeństwa przeznaczyłoby jeden wolny dzień w tygodniu właśnie na obowiązek pracy! W tym momencie ważne jest, by ukazać, iż te same badane osoby skłonne były zwierzyć się $\mathrm{z}$ tego, że ich życie jest pozbawione głębszego sensu i nietreściorodne oraz sprawia im trudność nawiązywanie szczerych i głębokich relacji, a co za tym idzie, nie czerpią radości ani satysfakcji z interakcji międzyludzkich ${ }^{6}$. Stykamy się więc z przygnębiającym paradoksem, albowiem poczucie czasowości jest stanem subiektywnym, dlatego też należy samemu zadać sobie pytanie, czy zaniedbywanie jednej mniej aprobowanej płaszczyzny życia społeczno-kulturowego na rzecz innej sfery jest grą wartą świeczki?

Faktem jest, że tak zwany „brak czasu” związany jest z naszą ponowoczesną i płynną epoką, która doprowadza człowieka do stanu psychologicznego

\footnotetext{
3 Tamże, s. 39.

${ }^{4}$ Tamże.

${ }^{5}$ Zob. P. Zimbardo, J. Boyd, Paradoks czasu, Warszawa, 2011.

${ }^{6}$ Zob. tamże.
} 
„przebodźcowania”. Nieprzerwanie docierające informacje mogą stać się powodem zamętu w naszych umysłach. Nie potrafimy nadążyć za hybrydycznym światem, co w konsekwencji doprowadza do tego, że człowiek czuje się zagubiony. Łakniemy sukcesów wielowymiarowych ${ }^{7}$, pragniemy być zabezpieczeni finansowo, mieć kochającego partnerkę/partnera, zdolne i zdrowe dzieci, doskonale układające się kontakty z innymi ludźmi oraz olśniewający dom z ogródkiem. Jak widzimy, liczba zapotrzebowań stale rośnie, a my przecież nie lubimy być stawiani przed wyborem, albowiem wiąże się z nim następstwo pod postacią rezygnacji z czegoś, co doprowadza do tego, że nie czujemy się dobrze. Jak zwraca uwagę Zimbardo, często żyjemy w sidłach nieświadomości danych zachowań, dlatego jako ofiary „braku czasu” rzucamy się w manipulacyjny wir stresów, frustracji i pracoholizmu. Jednak, wchodząc głębiej w strukturę ludzkiego podejścia do tej sprawy, należałoby zaznaczyć, że jest to związane z jednostkową wewnętrzną perspektywą czasową, która jest zakorzeniona $\mathrm{w}$ każdym $\mathrm{z}$ nas.

Ludzkie nastawienie do czasu to fundamentalny element, który wpływa na podejmowane przez nas ogólnożyciowe decyzje. I tak, jeśli u kogoś przeważa perspektywa teraźniejsza ${ }^{8}$, to podejmuje on decyzje żywiołowo i niekonwencjonalnie, pod wpływem dużej ilości pierwiastka emocjonalnego. Ważne jest to, czy dana osoba ma w bieżącej chwili na coś ochotę i czy zaspokojenie danej żądzy sprawi jej radość. Liczy się głównie przyjemność „tu i teraz” oraz czerpanie radości z dnia codziennego. Osoby żyjące w ten oto sposób nie martwią się konsekwencjami, gdyż nastąpią one w bliżej nieokreślonej przyszłości, dlatego nie ma potrzeby się nią przejmować. Istnieją dwie strony medalu postępowania w sposób teraźniejszy. Jednostki cechujące się tą postawą potrafią bardzo dobrze się bawić, czerpią radość z codzienności, są kreatywne i lubiane w towarzystwie. Jednakowoż taka postawa, jak mawia Zimbardo, posiada także swoje minusy: ciągłe spóźnienia, słomiany zapał, brak skonkretyzowanych zadań i celów ${ }^{9}$. W związku z tym, że osoby z horyzontem teraźniejszym rzadko liczą się z konsekwencjami swoich działań (co wiąże się, oczywiście, z rozwojową niedojrzałością), częściej zagrażają im uzależnienia oraz wypadki samochodowe po spożyciu alkoholu.

Wspomniany wcześniej psycholog podkreśla zaś, że osoby, które nadmiernie skupiają się na przyszłości, tracą kontakt z rzeczywistością, mimo

\footnotetext{
7 Tamże, s. 131.

8 Tamże, s. 93-110.

9 Tamże.
} 
iż odznaczają się one zazwyczaj punktualnością i skutecznością ${ }^{10}$. Jednakże, myśląc wyłącznie o rezultatach, stajemy się mniej elastyczni, zestresowani, pozbawieni spontaniczności oraz usztywnieni. Do kategorii tej zaliczani są pracoholicy, a także ludzie nakładający na siebie coraz to więcej obowiązków ${ }^{11}$. Ważne jest, aby mieć świadomość tego, że bez „nuty luzu”, teraźniejszego odniesienia i dystansu do samego siebie szczęście nie jest możliwe. Pytanie, jak znaleźć idealny sposób na to, aby poczucie czasowości nie było źródłem poczucia dyskomfortu w naszym życiu? Zimbardo w sposób dosadny odpowiada, że istotne jest to, w jaki sposób postrzegamy przeszłość. Jeśli percypujemy ją pozytywnie, mamy mocno użyźnione poczucie bezpieczeństwa oraz cechuje nas stabilność poznawczo-emotywna - szanujemy rodzinę i przyjaciól, nie negujemy tradycji, znamy swoją tożsamość ${ }^{12}$. Jeśli wspominamy przeszłość, a co za tym idzie, nostalgiczne wydarzenia w sposób negatywny, rozpamiętujemy katastroficzne sytuacje nieustannie, bez wytchnienia, to możemy mieć problem $\mathrm{z}$ autorozwojem i rzutowaniem siebie w przyszłość, lękamy się wszelakich zmian, co uniemożliwia egzystencjalny progres. Jednakże przeszłość może ulegać modyfikowaniu. Jest tylko płynną konstrukcją naszej świadomości, której kreatorami jesteśmy my sami. Każde doświadczenie, niezależnie od tego, czy było pozytywne bądź negatywne miało niebagatelny wpływ na kształtowanie się naszej osobowości. Jak widzimy, wyżej skonkretyzowany życiowy sukces może zostać osiągnięty tylko wtedy, gdy przestaniemy spoglądać na otaczającą rzeczywistość przez pryzmat krępujących możliwości kajdan.

Philip Zimbardo w swej książce przytacza eksperyment przeprowadzony wcześniej przez Waltera Mischela. Ten ostatni proponował czteroletnim przedszkolakom, by zjadły jedno ciasteczko, jednak jeśli chwilę poczekałyby, to dostałyby następne ${ }^{13}$. Co się okazało, większość dzieci zjadła pierwsze ciastko natychmiastowo, od razu. Gdy jednostki te ukończyły osiemnasty rok życia, Mischel przeprowadził z nimi wywiady. Okazało się, że osoby, które kilkanaście lat wcześniej potrafiły oprzeć się pokusie, czyli ich gratyfikacja została odroczona w czasie, były przepojone rozbudowaną strukturą emotywną oraz inteligencją, rozwinęły kompetencje społeczne, w porównaniu do jednostek, które zjadły ciasteczko w sposób natychmiastowy. Osoby te lepiej

\footnotetext{
${ }^{10}$ Tamże, s. 126-138.

11 Tamże.

12 Tamże, s. 258-259.

13 Tamże, s. 186-187.
} 
radziły sobie w sytuacjach stresogennych, były cierpliwe, mniej usposobione apodyktycznie, pracowite oraz z mocno ugruntowanym poczuciem własnej wartości, co wpływało pozytywnie na relacje interpersonalne. Miały także lepsze wyniki na egzaminach SAT (Standard Achievment Test), które są podstawową bazą intelektualną przy poborze do college’u. Jednostkowa zdolność do odraczania w czasie gratyfikacji pozytywnie wpływa na przyszłościowe kompetencje i ustosunkowanie się do społeczno-zawodowych aktywności. Jeśli u danych osób występują pożądane, osobliwe cechy typu, nadziejotwórcze poczucie efektywności oraz pewność siebie, od razu następuje spadek zaburzeń neurotycznych, które uniemożliwiają skuteczne poczynania w sferze prywatnej, także w przestrzeni kariery zawodowej. By osiągnąć cele w życiu, nie należy być zakotwiczonym w mentalnej oraz skrajnie wykańczającej perspektywie przyszłościowej. Często jest tak, że jednostki, które błyskawicznie zaspokoiły hedonistyczną potrzebę na przykład zakupu nowego, luksusowego samochodu bądź też dostały wymarzony awans w pracy, nie potrafią przeżyć chwili „tu i teraz”, relaksując się i odpoczywając, ponieważ zarzucają sobie gnuśnie lenistwo ${ }^{14}$. Takie osobistości egzystują w wyimaginowanym konstrukcie umysłowym, który opisuje dzień jutrzejszy. Zimbardo, mówiąc o tych współczesnych psycho-dolegliwościach, zaznacza, że mamy do czynienia z pułapką czasu (time crunch $^{15}$ ).

Podczas wczytywania się $\mathrm{w}$ teorię profesora nie opuszczało mnie pytanie, czy ludzie skupieni głównie na perspektywie teraźniejszej mają szansę osiągnięcia określonych celów? W sferze potocznych dociekań, zakłada się, że te jednostki nastawione są do życia hedonistycznie, a biorąc pod uwagę konotacje ściśle filozoficzne, hedonizm odnosi się do postępowania przyjemnościodajnego, bezrefleksyjnego, które doprowadza do negatywnych konsekwencji zarówno moralnie, jak i obyczajowo. Osoby cechujące się fatalistyczną perspektywą teraźniejszości podkreślają, że nie należy podejmować żadnego wysiłku w życiu, albowiem ich działalność nie przyniesie pozytywnych wyników. Postawa fatalistyczna może doprowadzić jednostki do wyniszczającej organizm i umysł nerwicy noogennej, czy lęku dezintegracyjnego, poczucia bezwartościowości i braku kontroli ${ }^{16}$.

\footnotetext{
14 Tamże, s. 137.

15 Tamże.

16 Tamże, s. 177.
} 


\section{Orientacja temporalna}

Jeśli chcemy bardziej zrozumieć i zreinterpretować działania podmiotu w sferze praxis, musimy wpierw przyjąć daną kategorię czasową i sposób egzystowania jednostki w tym czasie. Jest to bowiem kategoria zgeneralizowana i bardziej fundamentalna w stosunku do celów, które istoty ludzkie sobie wyznaczają ${ }^{17}$. Jak podkreśla Gisela Trommsdorf: „Umiejętność poznawczego ujmowania czasu jest dla jednostki podstawą określania własnej osobliwej tożsamości”"18 i „podejmowania świadomej, podmiotowej aktywności”19. Josephn Nuttin pisze zaś: „Możliwość ludzka przekraczania przestrzeni czasowej w sposób prawie nieograniczony jest faktem, którego ważność dla zachowania i motywacji trudno przecenić" ${ }^{20}$. Postępowanie to możemy określić mianem „transgresji temporalnej”'. Na tej podstawie możliwe jest byśmy konstruktywnie rzutowali w przyszłość, określali cele do ich realizacji, a także podejmowali aktywne, elastyczne decyzje dotyczące funkcjonalności i esencjonalności wypadkowej naszych działań. Kategoria czasu jest obecna w psychologii w dwóch znaczeniach jako:

Czas fizyczny, obiektywny, zewnętrzny - zakorzeniony w rzeczywistości przyrodniczej, odmierzający jego zmiany oraz będący punktem odniesienia dla danych sytuacji.

Czas psychologiczny, wewnętrzny, subiektywny - pokazujący zmiany od strony subiectum. Czas przeżywany wewnętrznie ukazuje „czysty strumień świadomości” jako horyzont mentalny, w którym człowiek funkcjonuje.

Przepływ tego czasu jest zależny od jednostkowych cech i postawy życiowej $^{21}$. Czesław Nosal podkreśla, że ta forma czasu jest konstruktem poznawczym, tworzonym w osobowości i wyrażającym dynamizmy psychiczne ${ }^{22}$.

Pespektywa czasowa, jak powyżej zaznaczyłam przy omawianiu najistotniejszych punktów Zimbardowskiej koncepcji czasowości, dotyczy wszyst-

\footnotetext{
17 R. Klamut, Cel, czas, sens życia, Lublin 2002, s. 45.

${ }^{18} \mathrm{G}$. Trommsdorff, Future time perspective and control orientation: Social conditio and consequences, [w:] Psychology of future orientation, ed. Z. Zaleski, Lublin 1994, s. 39-62.

${ }^{19} \mathrm{Cz}$. S. Nosal, Style percepcji czasu: wymiary i struktura. Propozycja nowej skali pomiarowej, [w:] Psychologiczne i psychometryczne problemy diagnostyki psychologicznej, red. J. Brzeziński Poznań 1993, s. 121-141.

${ }^{20}$ R. Klamut, dz. cyt., s. 45.

${ }^{21}$ Zob. W. Łukaszewski, Szanse rozwoju osobowości, Warszawa 1984.

${ }^{22}$ Zob. Cz. S. Nosal, Psychologiczne modele umystu, Warszawa 1990.
} 
kich trzech wymiarów czasu: przeszłości, teraźniejszości, przyszłości przy szczególnej zindywidualizowanej wizji rozumienia i przeżywania. Jak zaznacza Dariusz Śleszyński, życie „jest aktywnością zaangażowań i kształtuje się na bazie pewnej ciągłości, ewoluowania od przeszłości do przyszłości przez obecne działania"23. Jednostki ludzkie mają wpojone pewne mentalne pryncypia oraz dany zasób erudycyjny w celu podejmowania zadań pojawiających się w aktualnej sytuacji. Egzystując w cywilizacji technologicznej i konsumpcyjnej intuicyjnie zauważamy, że jądro tej zmechanizowanej kultury stanowią cele i motywacje ekonomiczno-materialistyczne, co jest ściśle związane $\mathrm{z}$ ukonstytuowaniem się systemu wartości opartego na ilościowym sposobie rozumienia $\mathrm{czasu}^{24}$.

Przytoczony powyżej czas ilościowy doprowadza do tego, iż przeformułowane zostaje Protagorejskie hasło, że to człowiek jest miarą wszechrzeczy istniejących, że istnieją, nieistniejących, że nie istnieją. Miarą współczesnego człowieka zaczyna być wydajność, albowiem człowiek staje się w tych cyfrowych czasach instrumentem i zbędną częścią procesu produkcyjnego, jego działalność i stan pracy zostały poddane rygorowi stałego przyspieszenia. Człowiek, dążący do przyspieszenia efektów produkcyjnych, przez udoskonalone mechaniczne narzędzia i modernizacji produkcji, „tym samym przyspiesza sam siebie jako narzędzie myślące, niezbędne do uzyskania tego przyspieszenia. W toku podwójnej szybkości procesu produkcyjnego i konsumpcji zanika jakościowy stosunek do pracy, a ilościowy, jednokierunkowy, stanowiący otwarte kontinuum czas staje się narzędziem ucisku człowieka"25. Trafnie ujął zarysowaną przeze mnie jednostkę Neil Postman:

Jest to osoba, której wartość mierzy się wydajnością działania. Celem dla niego, godnym każdej ofiary, jest idea postępu. Nauka jest jedynym systemem zdolnym tworzyć prawdę. Nie ma więc pascalowskiego dylematu między ładem rozumu i serca. Jest tylko porządek rozumu. Osiągnięcia technologiczne reprezentują najwyższą możliwą formę ludzkich osiągnięć. Tradycja, religia, wartości są pustymi pojęciami bez właściwości produktywnych i znaczenia utylitarnego. Empatia, lojalność, więzi są zbędnym balastem umysłu twórczego ${ }^{26}$.

${ }^{23}$ Zob. D. Śleszyński, Człowiek $w$ działaniu. Analiza empiryczna, fenomenologiczno-egzystencjalna, Białystok 1995.

${ }^{24}$ A. Pawełczyńska, Czas człowieka, Wrocław 1986, s. 164.

25 Tamże, s. 165.

${ }^{26}$ N. Postman, Technopol. Triumf techniki nad kultura, tłum. A. Tanalska-Dulęba, Warszawa 2004, s. 123. 
Józef Kozielecki niejednokrotnie zaznaczył, że człowiek to homo transgressivus, którego ambicje wykraczają poza Słupy Heraklesa. Jednak nie wszystkie jednostki w jednakowym stopniu są ekspansywne i innowacyjne ${ }^{27}$. Dlatego też Małgorzata Sobol-Kwapcińska w swym artykule Dialogi temporalne: $J a-w$ trzech wymiarach czasu $^{28}$ zaznacza, że człowiek jako istota intencjonalna rzutuje $\mathrm{w}$ przyszłość i ma świadomość egzystowania w określonych ramach czasowych, które pozytywnie bądź destrukcyjnie wpływają na jego sposób percypowania oraz realizowania danych celów i zapatrywań. Prowadzimy z czasem dialogi, by nasze życie było spójne i sensotwórcze. Prowadzimy je, gdy „przypadkowy bodziec (np. zdjęcie) wywoła w nas wyraziste wspomnienie nas samych z jakiegoś momentu z przeszłości; gdy dokonujemy większych lub mniejszych bilansów przeżytego czasu; gdy powracamy myślami do przeszłości (np. w związku z doznaną krzywdą lub gdy podejmujemy próbę samousprawiedliwienia); gdy formułujemy plany i cele; gdy wahamy się, jaką podjąć decyzję. Nie oznacza to jednak, że wszelkie procesy tego typu mają charakter dialogowy, a jedynie, że mogą mieć lub że u niektórych ludzi przybierają tę postać” ${ }^{\prime 2}$. Ważnym aspektem tak zwanych dialogów temporalnych jest ich funkcjonalność oraz koegzystencja współpracujących ze sobą horyzontów czasowych, co może doprowadzić człowieka do poznania swojej tożsamości oraz autowiedzy. „Rozmowy” temporalne nie mają być tylko mentalną kreacją, winny cechować się swoistym pragmatycznym użyciem, spełniają one różnorakie funkcje ${ }^{30}$ :

W sparcia ${ }^{31}$ - poprzez świadomość tego, że czas przeszły może wpływać kojąco na jednostki, albowiem „Ja przeszłościowe” lub przyszłościowe są pewnymi pocieszycielami w sytuacjach granicznych. Mogą one wysyłać wspomagające informacje swoistego rodzaju: „Czas leczy rany”, „Kiedyś o tym zapomnisz”, „To nie koniec świata. Ta sytuacja nie zaważyła na całym twoim życiu". Jak widzimy poparcie z pozycji przyszłościowej bądź przeszłościowej może mieć decydujący wpływ na harmonijne dopasowanie horyzontów poczucia czasowości.

\footnotetext{
${ }^{27}$ J. Kozielecki, Człowiek wielowymiarowy, Warszawa 1998, s. 11-12.

${ }_{28}$ M. Sobol-Kwapińska, Dialogi temporalne: Ja - w trzech wymiarach czasu, [w:] Życie na czas. Perspektywy badawcze postrzegania czasu, red. G. Sędek, S. Bedyńska, Warszawa 2010, s. 398.

${ }^{29}$ Tamże.

${ }^{30}$ Tamże, s. 415.

${ }^{31}$ Tamże.
} 
Redefiniowania przeszłości ${ }^{32}$ - funkcja ta polega przede wszystkim na próbie przyjrzenia się swoim doświadczeniom z nowego, świeżego oraz zdystansowanego punktu wiedzenia. Co znaczy, że podmiot stara się przeformułować negatywne przeżycia, by wyciągnąć $\mathrm{z}$ nich najkorzystniejsze dla siebie wnioski. Dzięki przewartościowaniu dotychczasowego paradygmatu myślowego, jednostka może odczytać nowe znaczenia, które budująco mogą wpłynąć na jej poczynania i koncentrację w świecie.

Bilan sowania ${ }^{33}$ - polegająca na tym, że jednostka ma prawo do oceny wartości swoich czynów, do prowadzenia porównań, dotyczących zysków i strat oraz sukcesów i porażek. Interesujący wydaje się fakt, że człowiek może wówczas skonfrontować swój marzycielski punkt widzenia z dotychczasowym czasem przeżytym, z empirią. Bilansowanie naszego życia może dopomóc nam w ujrzeniu osobistych dziejów wielowymiarowo, doceniając pozytywne i negatywne jego przejawy.

Dystansowania się ${ }^{34}$ - przybierając postawę antycentryczną; samodystansowanie się daje impuls do tego, by oderwać się od perspektywy swojego doświadczenia na rzecz innego, obiektywnego, jakościowego umiejscowienia siebie w sytuacji. Dystansowanie się skutkuje tym, że pomaga człowiekowi uświadomić sobie, iż egzystencjalne trudności czy korzystne powodzenia kiedyś się skończą. Poprowadzenie dialogu czasowego pomaga w zwalczaniu problemu "zamknięcia w czasie” - czyli kompulsywnego, schizoidalnego, nerwicowego zdania o niemożności zmiany siebie i swojego położenia sytuacyjnego.

D o r a d zan i a ${ }^{35}$ - pod postacią porad i wskazań z perspektywy przeszłości i przyszłych przewidywalnych wydarzeń. „Ja z przeszłości” i „Ja z przyszłości" pełnią funkcję swoistego coacha, który podpowiada, jak w danej sytuacji należałoby postąpić. Przysłuchiwanie się głosom z przeszłości pozwala korzystać z zasobów energetycznych, intelektualnych i witalnych, które niegdyś sprawdzone, dały pozytywne efekty.

Podejmowania decyzji ${ }^{36}$ - jest to zderzenie różnych, często przeciwstawnych perspektyw czasowych, które wyznaczają model danych postępowań. W perspektywie teraźniejszej częstokroć mamy problem z przepracowaniem negatywnych doświadczeń z przeszłości. Biorąc pod uwagę

\footnotetext{
32 Tamże.

33 Tamże.

${ }^{34}$ Tamże.

35 Tamże.

${ }^{36}$ Tamże.
} 
codzienny trud życia, niektóre sprawy mogą się wydać błahe i nieistotne, dlatego też tracą na swej wartości. Jednak myślenie alternatywne rozbudowuje nasz system oglądu w sferze prywatno-zawodowej. Możemy wybrać między pracą dobrze płatną, lecz pochłaniającą wszelkie siły zdrowotne i umysłowe, a pracą trochę mniej płatną, ale zostawiającą nam weekendy i popołudnia na relaks, pasję oraz spędzenie czasu w gronie najbliższych osób.

Nabywania mądrości ${ }^{37}$ - funkcja ta może dopomóc jednostkom w sformułowaniu pryncypiów moralnych, dyrektyw etycznych scalających jego interakcje społeczne. Prowadzenie dialogów temporalnych, innymi słowy, świadome sterowanie horyzontami czasowymi umacnia jednostkowe i zbiorowe poczucie sensowności i wartości życia oraz ma ogromny wpływ na stan emotywno-wolicjonalny.

Opanowania przyszłości ${ }^{38}$ - jest to jedna $z$ najistotniejszych funkcji, która może mieć kuriozalny wpływ na kształtowanie się przyszłościowych odniesień. Stopniowe kontrolowanie planów życiowych związane jest $\mathrm{z}$,Ja potencjalnym”, przepełnionym nadziejami, stratami i celami, które można urzeczywistnić. Dialog z „Ja możliwym” pomaga w wykreowaniu "Ja teraźniejszego", które planuje, motywuje się, ma umiarkowane podejście do sfery karierotwórczej. Dzięki takim dialogom jednostki mogą redukować swoje lęki związane z przyszłymi dokonaniami i zaniechaniem oraz umacniać poczucie ciągłości Ja. Jeśli mamy kontakt ze sobą z przeszłości i przyszłości, jednostka zyskuje poczucie własnej tożsamości i nierozbitej jaźni, pomimo biegnącego czasu.

Widzimy, że prowadzenie rozmów z własnym, subiektywnym odczuciem czasu może mieć katastroficzne następstwa. Konsekwencje te często u młodych osób ukazują się pod postacią frustrujących, degradujących psychikę frazesów typu: „Nie uda ci się osiągnąć tego a tego” ${ }^{39}$. Brzmi to jak przysłowiowy gwóźdź do trumny, zamykający wielokierunkowe furtki autopoznania i rozwoju osobistego. Właściwie, chodzi o to, aby pojmować temporalność jako osobisty wymiar życia. Partnerem w dyskusji jest dla nas zawsze nasz osobisty, niezbywalny czas, który powinien być rozumiany holistycznie i nominalistycznie, na przykład jako czas studiów bądź jako czas spędzony w gronie bliskich przyjaciół. Istotą dialogu temporalnego jest to, że zdajemy sobie sprawę, ile ten poświęcony czas wniósł w istnienie osoby, z czego ją ogołocił,

\footnotetext{
37 Tamże.

38 Tamże.

${ }^{39}$ Tamże, s. 418.
} 
czego nauczył i co zmienił. Nadanie czasowi wymiaru ludzkiego, ułatwia pojęcie nam jego istoty, esencjonalności, dzięki czemu w naszej umysłowości przedstawiają się obrazy z przeszłości bardziej pożądane, twórcze i mobilizujące wewnętrzne siły, by sprostać przeszkodom dnia dzisiejszego, które to mają niebagatelny wpływ na konstruowanie dnia jutrzejszego ${ }^{40}$.

\section{Egzystencjalny wymiar czasowości}

Odwołując się do psychologii oraz psychoterapii egzystencjalnej, należy naszkicować fakt, że w duchu tego psychologicznego odłamu człowiek nie istnieje substancjalnie, lecz nieustannie, nieprzerwanie rozwija się, kształtuje swoją jaźń oraz samoświadomość, wciąż się staje ${ }^{41}$. Zasadą ludzkiego bytowania jest nie tyle sum, ile sursum - nie tyle „jestem”, ile „wznoszę się w górę"42. Viktor Emil Frank $l^{43}$ czy Irvin Yalom podkreślają w swych fenomenalnych pracach, że istnienie człowieka w czasie rodzi pewne zobowiązania względem swojego rozwoju, autokreacji i projektowania swojej przyszłości.

Ciekawych informacji dostarczają nam, tak zwane Treningi Rozwoju Osobowości, o czym pisze Yalom ${ }^{44}$. W trakcie takiego treningu korzysta się ze specjalnych instrumentów, by wzbudzić w uczestnikach chęć dyskusji nad Sensem Życia. Proponuje się im, by wyobrazili sobie własne nagrobkowe epitafium. Wiele tego typu dociekań prowadzi do rozważań na temat takich kwestii, jak: egoizm, altruizm, spełnienie, materializm, twórczość. Wielu ludzi uważa, że życiu nadaje sens wychodzenie poza własny horyzont (cel znajduje się poza nami), jak na przykład miłość dla sprawy, twórcze zaangażowanie, czy wolontariat.

Często ludzie, którzy dorobili się finansowej fortuny doświadczają upadków moralnych i przeżywają kryzys wartości, albowiem wielu z nich rozpoczyna swoją drogę sukcesu z wyraźnym, z góry ustalonym celem, aby „zrobić to a tamto" (z prędkością światła), tylko po to, by zarobić mnóstwo pieniędzy, żyć bezrefleksyjnie, komfortowo, wzbudzać szacunek wśród innych.

${ }^{40}$ Tamże, s. 419.

${ }^{41}$ Zob. A. H. Maslow, W stronę psychologii istnienia, tłum. I. Wyrzykowska, Warszawa 1986.

${ }^{42}$ G. Marcel, Homo viator. Wstęp do metafizyki nadziei, tłum. P. Lubicz, Warszawa 1984, s. 25.

${ }^{43}$ Zob. V. E. Frankl, Psychoterapia dla każdego, Warszawa 1978; tenże, Homo patiens, tłum.

R. Czarnecki, Warszawa 1976; tenże, Psycholog w obozie koncentracyjnym, tłum. S. Zgórska, Warszawa 1962.

${ }^{44}$ Zob. I. D. Yalom, Rozmawiaj o sensie życia, [w:] tenże, Dar terapii, tłum. A. Tanalska-Dulęba, Warszawa 2003. 
Co interesujące, niebagatelna liczba młodych ludzi, którzy osiągnęli sukces między trzydziestym a czterdziestym rokiem życia, staje przed odpowiedzią na druzgocące pytanie: „co teraz będzie?, „co z resztą mojego życia?”, „Co z jego drugą połową?”. Yalom zauważył wśród znanych sobie milionerów, że większość $\mathrm{z}$ nich działa tak samo: zakładają nowe spółki i próbują wskrzesić dawną pomyślność. Czym to jest spowodowane? Sądzę, iż dzieje się tak dlatego, że chcą sobie i innym udowodnić, że dotychczasowe finansowe powodzenie nie było sprawą przypadkową, lecz, że to dzięki ich sile woli i zaangażowaniu osiągnęli szczyty. Nieustannie wymagają od siebie więcej, podnosząc poprzeczkę. Nie potrzebują już kilku milionów w banku, by czuć, że są materialnie zabezpieczeni. Zdają sobie sprawę z absurdalności i bezcelowości tego typu zachowania, jednak ich neurotyczne, nałogowe pragnienia wygrywają ze świadomością. Doskonale wiedzą, że marnują czas nie tylko sobie, ale przede wszystkim swoim najbliższym, nie potrafią jednak wycofać się z gry. Oni nie chcą robić interesów, oni muszą je robić - kieruje nimi wewnętrzny przymus. Pewien ceniony przedsiębiorca powiedział kiedyś Yalomowi, że gdyby przestał pracować, zatrzymał się na tym, co ma i co osiągnął, to by zniknął. Ludzie „mający wszystko” boją się nudy, gdyż nie mają pojęcia, jak ją zmienić w konstruktywną, pozytywną twórczość. Stale jesteśmy niezaspokojeni, albowiem pragnienia jako takiego nie da się nigdy zaspokoić. Gdy pojawia się w naszym umyśle jakaś „fanaberia”, od razu chce być ona spełniona. Następnie pojawiają się kolejne i jeszcze inne... Naturalnie pojawiają się momenty wytchnienia, przelotne chwile sytości, jednakowoż mimowolnie zamieniają się one $\mathrm{w}$ gnuśną nudę. $\mathrm{W}$ ten sposób pragnienia do spełnienia, do których dążymy, zmieniając się w nasze osiągnięcia, pozostawiają w nas pustkę, którą zapełniamy coraz to nowymi dążeniami, i tak bez końca: pragnienie - spełnienie pragnienia (osiągnięcie celu) - kolejne pragnienie i (być może) kolejne rozczarowanie.

Każda jednostka $\mathrm{z}$ osobna musi uświadomić sobie, że życie nie jest nieustannie wznoszącą się spiralą. Tylko neurotyk kasuje, detronizuje teraźniejszość, próbując znaleźć przeszłość w przyszłości ${ }^{45}$. Tyle, że przecież istnienia nie da się odłożyć na później. Już Sartre zaznaczał stanowczo, iż być odpowiedzialnym, to być niekwestionowanym sprawcą jakiegoś wydarzenia lub przedmiotu. Gdy uświadomimy sobie, że w świecie nie ma znaczenia poza „znaczeniem dla mnie”, nie ma znaczenia niezależnego, to egzystencja każdego z osobna nabierze artyzmu, dzięki czemu zmniejszy się irracjonalny lęk

${ }^{45}$ I. D. Yalom, Psychoterapia egzystencjalna, tłum. A. Tanalska-Dulęba, Warszawa 2008, s. 171. 
cechujący częstokroć ludzi ${ }^{46}$. Twórca psychologii postaci, Fritz Pearls, próbował pomóc swoim pacjentom w dopełnieniu ich niedokończonych spraw, w odblokowaniu świadomości, braniu na siebie odpowiedzialności ${ }^{47}$. Psychoterapeuci egzystencjalni radykalnie zaznaczają, że nic wartościowego w życiu nie przychodzi bez wysiłku: „Człowiek jakiego odkrył Freud - napisał Rollo May - był człowiekiem kierowanym, nie - kierującym"48. Sądził, że teoria freudowska wyniosła nieświadomość do funkcji anulującej odpowiedzialność. Józef Tischner uwidacznia, że:

[...] czas odsłania i zasłania, czas niszczy i buduje. Sam człowiek może w rozmaity sposób odnosić się do tego, co czas niesie i zabiera. Może zapominać się w dawno przebrzmiałej przeszłości, może zatracić siebie w kolorach teraźniejszości, może wszystkie swe tęsknoty umieszczać w przyszłości. Sens czasu jest sensem bytowania. Tak człowiek uczasawia czas. Jest on jedyną w świecie istotą, która może zrobić coś ze swoim czasem. Człowiek jest dziejowy, bo uczestnicząc w historii, dzieje się sam ${ }^{49}$.

Dlatego też jednostki są stale skazane na korygowanie „transtemporalnego ja”, albowiem by dojść do zharmonizowanej osobowości, należałoby wpoić swojemu intelektualno-emotywnemu systemowi, iż „przeszłość jest czasowo i treściowo rozbudowana, a przyszłość czeka na zasobne wykorzystanie, bazując na teraźniejszych, efektywnych dokonaniach ${ }^{50}$.

\section{Podsumowanie}

Konkluzją, jaka zrodziła się przy okazji mojej refleksji nad wpływem fenomenu czasu i jego aspektem różnorodnego oddziaływania, jest stwierdzenie, że wypośrodkowana, optymalnie zrównoważona perspektywa temporalna (optimally balanced TP) wydaje się, z punktu widzenia zdrowia psychicznego oraz ludzkiej relacyjności, najkorzystniejszą propozycją. Dzięki temu proporcjonalnemu projektowi istoty ludzkie mogą nabrać dystansu względem swojego świata i jego efemerycznych zawiłości. Dzięki owej elastyczności mogą

\footnotetext{
${ }^{46}$ Tamże, s. 264.

${ }^{47}$ F. Perls, Wokót śmietnika, tłum. W. Marcysiak, Poznań 2002, s. 14.

${ }^{48}$ Zob. I. D. Yalom, Psychoterapia egzystencjalna.

${ }^{49}$ J. Tischner, Martina Heideggera milczenie o Bogu, [w:] Filozofia wspótczesna, red. J. Tischner, Kraków 1989, s. 100.

${ }^{50}$ Z. Zaleski, Transtemporalne „ja”: osobowość w trzech wymiarach czasowych, „Przegląd Psychologiczny", t. 31, 1988, nr 4, s. 940.
} 
swobodnie i płynnie przechodzić między danymi horyzontami temporalnymi, łącząc czy dzieląc jego elementy według własnych pragnień i oczekiwań oraz sytuacyjnych uwarunkowań. Istotny jest fakt, że Thomas Eriksen w swej książce Tyrania chwili ${ }^{51}$ uwypuklił nam problem, iż człowiek nastawiony jest do życia w sposób hiperszybki, pospieszny, co wpływa niekorzystnie na postrzeganie czasu jako powolnego upływu. Podkreśla on także, że doszło do fundamentalnej zmiany: „ze względnej powolności i liniowości na szybkość i chwilowość ${ }^{2}$. Czyż człowiek nie stał się „szybkomyślicielem”, zapominając tym samym o tym, że to on jest sternikiem na morzu czasowości? Czyż nie należy stanowczo uzmysłowić sobie, iż obiektywny, niezależny od nas czas jest tylko bezpieczną przystanią, czas subiektywny (przeżywany) zaś może nam dać impuls do tego, by nie wskakiwać do łódki, a zanurzyć się w gęstwinie czasowego doświadczenia? Tylko dzięki temu będziemy wiedzieli, czy płynąć z prądem, czy pod prąd.

\section{Bibliografia}

Eriksen T. H., Tyrania chwili. Szybko $i$ wolno płynacy czas w erze informacji, tłum. G. Sokół, PIW, Warszawa 2003.

Frankl V. E., Psychoterapia dla każdego, tłum. R. Czarnecki, IW PAX, Warszawa 1978. Homo patiens, tłum. R. Czernecki, PAX, Warszawa 1976.

Psycholog w obozie koncentracyjnym, tłum. S. Zgórska, PAX, Warszawa 1962.

Kinget M. G., On being human. A systematic view, Harcourt Brace Jovanovich, Inc, New York 1975.

Klamut R., Cel, czas, sens życia, TN KUL, Lublin 2002.

Łukaszewski W., Szanse rozwoju osobowości, Książka i Wiedza, Warszawa 1984.

Marcel G., Homo viator. Wstęp do metafizyki nadziei, tłum. P. Lubicz, IW PAX, Warszawa 1984.

Maslow A. H., W strone psychologii istnienia, tłum. I. Wyrzykowska, IW PAX, Warszawa 1986.

Nosal Cz. S., Psychologiczne modele umystu, PWN, Warszawa 1990.

Pawełczyńska A., Czas człowieka, Wyd. PAN, Wrocław 1986.

Perls F., Wokót śmietnika, tłum. W. Marcysiak, Zysk i S-ka, Poznań 2002.

Postman N., Technopol. Triumf techniki nad kulturą, tłum. A. Tanalska-Dulęba, Muza, Warszawa 2004.

${ }^{51}$ T. H. Eriksen, Tyrania chwili. Szybko i wolno płynący czas w erze informacji, tłum. G. Sokół, Warszawa 2003.

${ }^{52}$ Tamże, s. 148. 
Sobol-Kwapińska M., Dialogi temporalne: Ja - w trzech wymiarach czasu, [w:] G. Sędek, S. Bedyńska (red.), Życie na czas. Perspektywy badawcze postrzegania czasu, PWN, Warszawa 2010.

Śleszyński D., Człowiek $w$ działaniu. Analiza empiryczna, fenomenologiczno-egzystencjalna, Trans Humana, Wyd. Uniwersyteckie, Białystok 1995.

Tischner J., Martina Heideggera milczenie o Bogu, [w:] J. Tischner (red.), Filozofia współczesna, Kraków 1989.

Tucholska K., Kompetencje Temporalne jako wyznacznik dobrego funkcjonowania, TN KUL, Lublin 2007.

Trommsdorff G., Future time perspective and control orientation: Social conditio and consequences, [w:] Z. Zaleski (ed.), Psychology of future orientation, Lublin 1994.

Wolicki M., Teoria motywacji w ujęciu Victora Emila Frankla, „Zdrowie Psychiczne” 1988.

Yalom I. D., Psychoterapia egzystencjalna, tłum. A. Tanalska-Dulęba, Instytut Psychologii Zdrowia, Warszawa 2008.

Yalom I. D., Rozmawiaj o sensie życia, [w:] Dar terapii, tłum. A. Tanalska-Dulęba, Instytut Psychologii Zdrowia, Warszawa 2003.

Zaleski Z., Transtemporalne „ja”: osobowość w trzech wymiarach czasowych, „Przegląd Psychologiczny", t. 31, 1988, nr 4.

Zimbardo P., Boyd J., Paradoks czasu, PWN, Warszawa 2011.

\section{Abstract \\ The Borderline of Psychology of Success or Healthy attitude to time management}

The point of presented article is to show moderate time perspective, on the basis of various psychological and philosophical ideas. Philip Zimbardo in his, intellectually stimulating, book called "Paradox of time" tries to show and enunciate "problem" of 21 st century, which is growing sense of "lack of time”. That connected is to unskillful time management. American social psychologist emphasise, that people doesn't respect time given them and acts like they are immortal creatures. From a point of existential psychology human being is in constant development. Balanced time perspective is there to help us constructively managing psychological time. Viktor Emil Frankl or Irvin Yalom emphasise in their phenomenal publications that human existence in time, cause certain obligations to self-development and designing its own future.

Key words: existential psychology, time perspective, physical time, psychological time, development 